\title{
Stability-Indicating Chromatographic Methods for Determination of Agomelatine in Drug Substance and Drug Product
}

\section{Mohamed Rizk ${ }^{1}$, Elham A Taha ${ }^{2}$, Maha M Abou El-Alamin ${ }^{1}$ and Yasmine M Sayed ${ }^{2}$}

${ }^{1}$ Analytical Chemistry Department, Helwan University, Cairo, Egypt

${ }^{2}$ National Organization for Drug Control and Research (NODCAR), Giza, Egypt

"Corresponding author: Yasmine M Sayed, National Organization for Drug Control and Research (NODCAR), 6 Abu Hazem Street, Pyramids Ave., P. O. Box 29, Giza, Egypt, Tel: +20 2 37484988; E-mail: drjassey.m.86@gmail.com

Received date: January 11, 2017; Accepted date: January 29, 2017; Published date: January 31, 2017

Copyright: @ 2017 Rizk M, et al. This is an open-access article distributed under the terms of the Creative Commons Attribution License, which permits unrestricted use, distribution, and reproduction in any medium, provided the original author and source are credited.

\begin{abstract}
Three sensitive and validated chromatographic methods were developed for determination of Agomelatine (AGO) in the presence of its degradation products in drug substance and drug product. The first and second methods were normal thin layer chromatographic (NP-TLC) and reversed phase thin layer chromatographic (RP-TLC) methods. Mobile phase consisting of ethyl acetate-ammonia (33\%)-methanol $(8.5: 0.5: 1, \mathrm{v} / \mathrm{v} / \mathrm{v})$ was used for NP-TLC while for RP-TLC using $0.1 \%$ triethylamine (TEA): acetonitrile $(60: 40 \mathrm{v} / \mathrm{v})$ at $\mathrm{pH}=2$. The chromatograms were scanned at 230 and $280 \mathrm{~nm}$ and determined in the range of 0.1-4 and 0.3-4 $\mathrm{\mu g} / \mathrm{spot}$ with mean percentage recovery of $99.89 \pm$ 1.141 and $100.01 \pm 1.062$ for NP-TLC and RP-TLC respectively.

The third method was Micellar Liquid Chromatographic (MLC) method using $\mathrm{C}_{18}$ column and a mobile phase consisting of $0.1 \mathrm{M}$ Sodium Dodecyl Sulphate (SDS), $15 \%$ butan-1-ol, $0.2 \% \mathrm{TEA}$ in water adjusted to $\mathrm{pH}=3$. The UV detection was achieved at $230 \mathrm{~nm}$ and determined in the range of $0.5-5 \mu \mathrm{g} / \mathrm{mL}$ with mean percentage recovery of $100.13 \pm 0.970$. The proposed methods were successfully applied as stability indicating methods under different stressed conditions according to the International Conference of Harmonization (ICH) guidelines. The methods showed good selectivity, repeatability, linearity and sensitivity according to the evaluation of the validation parameters.
\end{abstract}

Keywords: Agomelatine; Micellar Liquid Chromatographic (MLC); Thin layer chromatographic; Reversed phase; Stability-indicating

\section{Introduction}

Agomelatine (AGO) is the first melatonergic antidepressant, displays a non-monoaminergic mechanism.

As AGO addresses sleep disturbances as well as depressive symptoms and has early onset of action, even in severely depressed patients, it stands alone among the antidepressants for effective management of major depressive disorders (MDD) [1].

It is a naptha-lenic compound chemically designated as $\mathrm{N}-[2-(7-$ methoxynaphth-1-yl) ethyl] acetamide (Figure 1). It has an empirical formula of $\mathrm{C}_{15} \mathrm{H}_{17} \mathrm{NO}_{2}$ [2].

It has a high agonist affinity at melatonin $\left(\mathrm{MT}_{1}\right.$ and $\left.\mathrm{MT}_{2}\right)$ receptors. It is also an antagonist of 5-hydroxytryptamine $\left(5-\mathrm{HT}_{2} \mathrm{C}\right.$ and $\left.5-\mathrm{HT}_{2} \mathrm{~B}\right)$ serotonin receptors.

It displays an overall selectivity (>100-folds) for $\mathrm{MT}_{1}$ and $\mathrm{MT}_{2}$ receptors as compared to other receptor sites.

The pharmacology of AGO is different to all other antidepressants currently available. And this may exhibit clinically as improvements in mood, anxiety and sleep-wake cycles with MDD, indicate that AGO is a potentially useful treatment for major depressive episodes in adults $[1,3]$.<smiles>COc1ccc2cccc(CCNC(C)=O)c2c1</smiles>

Figure 1: Chemical structure of Agomelatine.

The literature survey reveals several methods for determination of AGO in plasma by High Performance Liquid Chromatographic (HPLC) method with fluorescence detection [4,5], UV detection [6-8] and mass spectrometry $[9,10]$. Electro Kinetic Chromatography (EKC) method [11] and high performance thin layer chromatography (HPTLC) method [12] were also developed.

TLC method is considered to be a good alternative, and it should be widely explored as an important tool in routine drug analysis. A major advantage of TLC is its ability to analyze several samples simultaneously using a small quantity of mobile phase. This reduces the time and cost of analysis, minimizes exposure risks, and 
Page 2 of 9

significantly reduces disposal problems of toxic organic solvents, thereby reducing the possibilities of environment pollution [13].

MLC was first introduced by Armstrong and Henry [14]. It is an alternative technique to conventional reversed phase liquid chromatography (RPLC) in which the mobile phases are aqueous solution of surfactant at a concentration above critical micelle concentration (c.m.c.) where they associate to form aggregates called micelles. This has made these systems are applicable separation methods [15].

The slaw solutes transfer between the micelles and the stationary phase results in band broadening which affects the high efficiency that is obtained in MLC. Therefore, increasing temperature, decreasing the flow rate or the addition of organic modifiers which is usually short chain alcohol to the mobile phase increase the elution strength, improve the shape of chromatographic peaks and improve efficiency in MLC by solvating the bonded stationary phase and reduce amount of surfactant adsorbed [14,15].

To our knowledge no stability indicating MLC method was reported for AGO. The aim of this work is to perform more accurate, reliable, fast and validated MLC and TLC methods for determination of AGO in drug substance and drug product with a simple and rapid sample preparation especially for the routine analysis. Different chromatographic parameters were investigated to select the optimum conditions for separation and for application as stability-indicating methods for determination of AGO according to ICH guideline [16].

\section{Experimental}

\section{Instrumentation}

The NP-TLC and The RP-TLC methods were performed on CAMAG Linomat 5 TLC scanner (Muttenz, Switzerland) using TLC silica gel $60 \mathrm{~F} 254$ aluminum sheets plates $(10 \times 10 \mathrm{~cm}$ with $0.2 \mathrm{~mm}$ thickness, E. Merck, Germany) and TLC silica gel 60 RP-18 F254 S aluminium sheets plates $(10 \times 10 \mathrm{~cm}$ with $0.2 \mathrm{~mm}$ thickness, E. Merck, Germany) and spots of the samples were applied in the form of bands of width $3 \mathrm{~mm}$ and $6 \mathrm{~mm}$ using CAMAG Linomat 5 sample applicator with $100 \mu \mathrm{L}$ syringe for NP-TLC and RP-TLC respectively.

The MLC method was performed on Agilent 1200 series LC (Germany) equipped with quaternary gradient pump, variable wavelength UV detector and a manual injector Rheodyne valve with 20 $\mu \mathrm{L}$ fixed loop.). The data was analyzed using Chemstation software. The mobile phase was filtered through Charles Austen Pumps Ltd. filter; modelB100 SE (England, UK) using $0.45 \mu \mathrm{m}$ millipore filters (Gelman, Germany) (Tokyo, Japan).

UV lamp with short wave length $254 \mathrm{~nm}$, (Desaga, German).

All the drugs and chemicals were weighed on Sartorius weighting technology $\mathrm{GmbH}$ (Gottingen-Germany).

The $\mathrm{pH}$ was measured with Jenway $\mathrm{pH}$ meter, 3510, (EssexUK).

Ultrasonic bath used was Falc, (TreviglioItaly).

Shimadzu UV-VIS 2450 spectrophotometer (Tokyo, Japan), connected with UV probe program with two matched $1 \mathrm{~cm}$ pathlength quartz cell.

\section{Materials and Methods}

Authentic sample: AGO (B.N.2AGM0020514) was kindly supplied by $\mathrm{Al}$-Rowad Pharmaceutical industrial Company. Its purity was found to be $99.3 \%$ as referred by the supplier [17]. Dosage form: VALDOXAN $^{\circ}$ film coated tablets (Batch No. 914403), labelled to contain $25 \mathrm{mg}$ of AGO manufacture by Les Laboratories Servier Industries, France and were packed by: SERVIER EGYPT INDUSTRIES LIMITED, A.R.E. They were obtained from local market.

\section{Chemicals and reagents}

All Reagents were of Analytical Reagent Grade and solvents were of HPLC grade. Deionised water (SEDICO pharmaceuticals Co., Cairo, Egypt) was used throughout the study. Methanol, 1propanol, butan-1ol, ethyl acetate and acetonitrile (HPLC grade) were obtained from SigmaAldrich (Germany). Orthophosphoric acid (85\%, w/v), triethylamine (TEA) and sodium dodecyl sulphate (SDS, 99\%) were obtained from RiedeldeHaen (Sleeze, Germany), hydrochloric acid (Aldrich, Germany), sodium hydroxide and ammonia 33\% were purchased from (El Nasr Pharmaceutical Chemicals Co. Egypt). Hydrogen peroxide $(30 \%, w / v)$ was obtained from Luna industrial group (6th of October City, Egypt).

\section{Chromatographic conditions}

NP-TLC and RP-TLC methods were performed TLC silica gel 60 F254 aluminum sheets plates $(10 \times 10 \mathrm{~cm}$ with $0.2 \mathrm{~mm}$ thickness, E. Merck, Germany) and TLC silica gel 60 RP-18 F254 S alumminium sheets plates $(10 \times 10 \mathrm{~cm}$ with $0.2 \mathrm{~mm}$ thickness, E. Merck, Germany) in the form of narrow bands of $3 \mathrm{~mm}$ and $6 \mathrm{~mm}$ to the plate at $10 \mathrm{~mm}$ from the bottom and $10 \mathrm{~mm}$ from the side edges, and with $10 \mathrm{~mm}$ distance between each two bands for NP-TLC and RP-TLC respectively. Samples were applied under a continuous drying stream of nitrogen gas. The mobile phase is consisting of ethyl acetatemethanol-ammonia (33\%) (8.5:1:0.5 v/v/v) for NP-TLC method while for RP-TLC method, the mobile phase is consisting of $0.1 \%$ TEA: Acetonitril $(60: 40, v / v)$ at $\mathrm{pH}=2$ adjusted using ortho-phosphoric acid. Linear ascending development was carried out in a glass chamber (for $10 \times 10 \mathrm{~cm}$ ) previously saturated with mobile phase vapor for $10 \mathrm{~min}$. and $15 \mathrm{~min}$ for NP-TLC and RP-TLC respectively at $25 \pm 2^{\circ} \mathrm{C}$. After development the plates were completely dried in air. Densitometric scanning was performed in the absorbance mode and bands were scanned at 230 and $280 \mathrm{~nm}$ for NP-TLC and RP-TLC respectively. The slit dimensions were $5 \mathrm{~mm}$ length and $0.45 \mathrm{~mm}$ width, with a scanning speed of $10 \mathrm{~mm} / \mathrm{s}$ for both methods.

Optimized Chromatographic conditions are shown in Table 1.

MLC method was performed on Apollo $\mathrm{C}_{18}$ column $(250 \times 4.6 \mathrm{~mm}$, $5 \mu \mathrm{m}$ particle sizes). The mobile phase is consisting of $0.1 \mathrm{M}$ sodium dodecyl sulphate (SDS), $15 \%$ butan-1-ol, $0.2 \%$ triethylamine (TEA) in water adjust $\mathrm{pH}$ at 3 using ortho-phosphoric acid. It was filtered and sonicated for $15 \mathrm{~min}$ before use. The column was equilibrated for at least $2 \mathrm{~h}$ with the mobile phase. The flow rate was $1.2 \mathrm{~mL} / \mathrm{min}$ and sample injection volumes were $20 \mu \mathrm{L}$ at temperature $\left(50^{\circ} \mathrm{C}\right)$. The UV detector was operated at $230 \mathrm{~nm}$.

\section{Preparation of standard solutions}

Stock solutions: Stock solution of AGO was prepared by accurately weighing $10 \mathrm{mg}$ into $100 \mathrm{~mL}$ volumetric flasks, $20 \mathrm{~mL}$ methanol was 
added, shacked well and then completed to the mark with the same solvent to get $100 \mu \mathrm{g} / \mathrm{mL}$ stock solution for TLC and MLC methods.

Working solutions: Serial dilutions of AGO and was transferred into series of $10 \mathrm{~mL}$ volumetric flasks, completed to the mark with methanol to get $0.1-4 \mu \mathrm{g} / \mathrm{mL}, 0.3-4 \mu \mathrm{g} / \mathrm{mL}$ and $0.5-5 \mu \mathrm{g} / \mathrm{mL}$ working solutions for NP-TLC, RP-TLC and MLC respectively.

\section{Preparation of pharmaceutical products}

The content of 10 tablets of VALDOXAN film coated tablets were decoated, dried, accurately weighed and finely powdered. Tablet powder equivalent to $10 \mathrm{mg}$ of $\mathrm{AGO}$ was accurately weighted, dissolved in $20 \mathrm{~mL}$ methanol, sonicated for $15 \mathrm{~min}$ and filtered through Whatmann filter paper No. 41. The solution was transferred to a $100 \mathrm{~mL}$ volumetric flask and volume was made up to the mark with methanol to yield a solution containing $100 \mu \mathrm{g} / \mathrm{mL}$ of AGO.

Sample degradation: The degradation samples were prepared by transferring powdered tablets, equivalent to $100 \mathrm{mg}$ AGO into a 250 $\mathrm{mL}$ round bottomed flask. Then drug content was employed for acidic and alkaline stress conditions. After the degradation treatments were completed, the stress content solutions were allowed to equilibrate to room temperature and diluted with methanol to attain $1000 \mu \mathrm{g} / \mathrm{mL}$ AGO concentration.

Acidic and Alkaline degradation study was performed by heating the drug content under reflux in alcoholic $2 \mathrm{~N} \mathrm{HCl}$ and $2 \mathrm{~N} \mathrm{NaOH}$ for $2 \mathrm{~h}$ and the mixture was neutralized. Oxidation degradation study was performed by heating the drug content under reflux in $5 \% \mathrm{v} / \mathrm{v} \mathrm{H}_{2} \mathrm{O}_{2}$ for $1 \mathrm{~h}$.

\begin{tabular}{|l|l|l|}
\hline \multirow{2}{*}{ Parameters } & Chromatographic Conditions \\
\cline { 2 - 3 } & NP-TLC & RP-TLC \\
\hline Stationary phase & $\begin{array}{l}\text { Aluminium sheet TLC silica gel } \\
60 \text { F254 S plates }\end{array}$ & $\begin{array}{l}\text { Aluminium sheet TLC } \\
\text { silica gel 60 RP-18 } \\
\text { F254 S plates }\end{array}$ \\
\hline Mobile phase & $\begin{array}{l}\text { Ethyl actate: Methanol: Amm } \\
(33 \%)(80: 15: 5 \mathrm{v} / \mathrm{v})\end{array}$ & $\begin{array}{l}0.1 \% \text { TEA: Acetonitril at } \\
\mathrm{pH} 2(60: 40 \mathrm{v} / \mathrm{v})\end{array}$ \\
\hline Chamber saturation & $10 \mathrm{~min}$ & $15 \mathrm{~min}$ \\
\hline Sample applicator & CAMAGE Linomate 5 & $3 \mathrm{~mm}$ \\
\hline Band & $6 \mathrm{~mm}$ & $230 \mathrm{~nm}$ \\
\hline $\begin{array}{l}\text { Densitometric } \\
\text { scanner }\end{array}$ & CAMAGE Linomate 5 TLC scanner \\
\hline Wavelength & $280 \mathrm{~nm}$ & \multicolumn{2}{|l|}{} \\
\hline
\end{tabular}

Table 1: Optimization of TLC conditions for the separation of AGO.

\section{Results and Discussion}

\section{NP-TLC method}

The proposed NP-TLC method is depending on the differences in RF values of AGO and its alkaline, acidic and oxidative degradation products. The chromatographic conditions for the NP-TLC method were developed for the determination of AGO in the presence of its degradation products such as mobile phase composition, scan mode, and wavelength of detection. By studying different developing systems with different ratios, the most suitable one with good RF values was ethyl acetate-methanol-ammonia (33\%) in the ratio of $(8.5: 1: 0.5 \mathrm{v} / \mathrm{v} / \mathrm{v})$ which gave a good resolution and compact spots for both AGO and its degradation products with RF value $0.58 \pm 0.04$ for AGO (Figure 2).

The scan mode chosen was the absorbance mode and swing width was $10 \mathrm{~mm}$.

Different scanning wavelengths were tried but the best sensitivity was at $230 \mathrm{~nm}$.

By applying the proposed NP-TLC method, a linear correlation was obtained between the area under the peak and the concentration in the range of $0.1-4 \mu \mathrm{g} / \mathrm{spot}$ (Figure 3 ).

\section{RP-TLC method}

The proposed RP-TLC method was developed for routine analysis of AGO. Selection of the mobile phase was carried out on the basis of polarity. A mobile phase that would give a dense and compact band with an appropriate RF value for AGO and degradation products was desired. Various mobile phases such as methanol-water, methanol$0.5 \%$ TEA, methanol-acetonitril-water, methanol-0.05 m phosphate buffer $\mathrm{pH} 2.5$, acetonitril-water, acetonitril-0.5\% TEA, acetonitril-0.05 $\mathrm{m}$ phosphate buffer $\mathrm{pH} 2.5$, and acetonitril-0.1\% aqueous orthophosphoric acid- $0.15 \%$ TEA were tried in different proportions.

A mobile phase consisting of $0.1 \%$ TEA: Acetonitril $(60: 40, v / v)$ at $\mathrm{pH}=2$ adjusted using orthophosphoric acid gave good separation of AGO from its degradation products with RF value $0.54 \pm 0.02$ for AGO. The scan mode chosen was the absorbance mode and swing width was $10 \mathrm{~mm}$. Different scanning wavelengths were tried but the best sensitivity was at $280 \mathrm{~nm}$. These chromatographic conditions produced a well-defined, compact and non-diffuse band of AGO with good resolution and a sharp symmetrical peak (Figure 4). A linear correlation was obtained between the area under the peak and the concentration in the range of $0.3-4 \mu \mathrm{g} / \mathrm{spot}$ (Figure 5).

\section{MLC method}

The proposed MLC method represents a simple and sensitive stability-indicating assay method for the simultaneous determination of AGO in bulk and commercial tablets. Different parameters affecting the chromatographic performance of AGO were carefully studied in order to achieve the most suitable chromatographic system. The results of the optimization study can be summarized as follows.

Choice of appropriate detection wavelength: AGO exhibited maximum absorption at 230 and $280 \mathrm{~nm}$ when measured in methanol. $230 \mathrm{~nm}$ was selected as it gives reasonable sensitivity. The absorption spectrum of AGO in methanol is shown in Figure 6.

Optimization of the mobile phase: The chromatographic conditions were optimized to provide sufficient simplicity, selectivity and suitability in a short separation time and good resolution between the drug and its degradation products. The variables were studied include: the $\mathrm{pH}$ of the mobile phase, concentration of SDS, organic modifier and TEA, flow rate and temperatures.

PH of the mobile phase: Different $\mathrm{pH}$ was studied 2.5, 3.5 and 6. The $\mathrm{pH}=3$ adjusted using ortho-phosphoric acid were selected as the optimum $\mathrm{pH}$ value for the mobile phase which give the highest number of theoretical plates with good peak shape and symmetry (Figure 7). 
Concentration of SDS: Concentration of SDS was varied in different range from $0.05-0.20 \mathrm{M}$. The highest the molar concentration of SDS the lowest the retention time of the drug but the $0.2 \mathrm{M}$ SDS showed lower number of theoretical plates and higher peak tailing than $0.1 \mathrm{M}$ SDS. The $0.1 \mathrm{M}$ SDS was selected as the optimum concentration for the mobile phase.

Type and concentration of organic modifier: Three different organic modifiers were tested including 1propanol, acetonitrile and butan-1-ol The butan-1-ol has been selected as the optimum organic modifier where the acetonitrile did not separate the degradation products and the 1propanol separated the drug at high retention time and bad peak resolution. The concentration of butan-1-ol was varied in different range from $10-20 \%$. As expected, the drug's retention time decreases as organic modifier's percentage increases. A concentration of $15 \%$ of butan1-ol was selected as the optimal concentration, where it gave a good retention time and peak symmetry where a concentration of $20 \%$ of butan1-ol gave the lowest number of theoretical plates.

Concentration of triethyl amine (TEA): TEA is added to the mobile phase to reduce the tailing of basic compounds. Different Concentration of TEA was used in the range of $0.10 .3 \%$. It was found that the peak asymmetry and number of theoretical plates were higher with $0.2 \%$ TEA

Flow rate of the mobile phase: The effect of flow rate of the mobile phase was studied using the range of 1.0 and $1.2 \mathrm{~mL} / \mathrm{min}$. It was found that flow rate of $1-2.0 \mathrm{~mL} / \mathrm{min}$ provide high peak asymmetry, high number of theoretical plates and good peak shape within a better retention time.

\section{Temperature}

It was found that the drug's retention time decreases as temperature increases where the number of theoretical plates increases. A temperature of $50^{\circ} \mathrm{C}$ was selected as the optimal one.

Finally, a mobile phase $0.1 \mathrm{M}$ SDS, $15 \%$ butan-1-ol, $0.2 \%$ TEA in water adjusted to $\mathrm{pH}=3$ at flow rate of $1.2 \mathrm{~mL} / \mathrm{min}$ and at temperature $=50^{\circ} \mathrm{C}$ was selected as it give the best peak shape and good sensitivity within a $10 \mathrm{~min}$ run time. The retention time was $5.4 \mathrm{~min}$. for AGO. Wavelength was set at $230 \mathrm{~nm}$, which provided better reproducibility with minimum or no interference.

\section{Method validation}

The validity of the proposed methods was assessed by studying the following parameters in accordance to ICH guideline [16]: Linearity, range, LOD, LOQ, accuracy, precision, selectivity, sample solution stability, system suitability and robustness.

\section{Linearity and ranges}

Under the optimum chromatographic conditions, a linear relationship was established between peak under the area in NP-TLC, RP-TLC and MLC methods and drug concentration in the range of $0.1-4 \mu \mathrm{g} / \mathrm{spot}, 0.3-4 \mu \mathrm{g} / \mathrm{spot}$ and $0.5-5 \mu \mathrm{g} / \mathrm{mL}$ respectively (Figures $8-10)$. The high value of correlation coefficient (r) and Relative Standard Deviation (RSD) according to the following regression equation assured the validity of the methods and their coinciding with Beer's law system as showed with other regression parameters in Table 2.

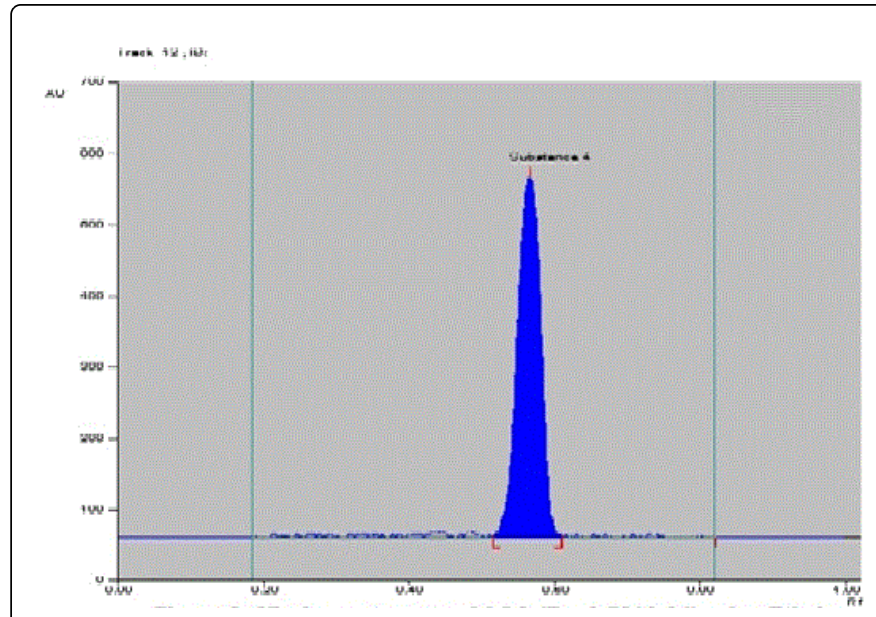

Figure 2: 2D Chromatogram of AGO $(\mathrm{Rf}=0.58 \pm 0.04)$ using Ethyl acetate: $\mathrm{MeOH}: \mathrm{Amm}$. (33\%) $(85: 10: 5, \mathrm{v} / \mathrm{v} / \mathrm{v})$ as mobile phase at 230 nm by NP-TLC method.

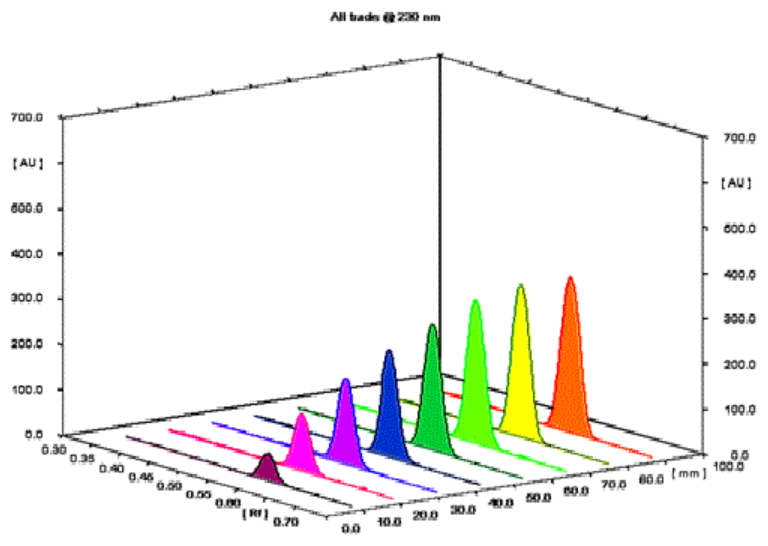

Figure 3: 3D Chromatgram of calibration bands of AGO $(0.1-4 \mu \mathrm{g} /$ spot) at $230 \mathrm{~nm}$ by NP-TLC method.

\section{Accuracy}

To prove the accuracy of the proposed methods, the results of the assay of AGO in bulk by the proposed NP-TLC, RP-TLC and MLC methods were compared with those obtained using a reference HPLC method [17]. Statistical comparison using t-test and F-test revealed no significant differences between the performance of the three methods regarding the accuracy and precision, respectively as illustrated in Table 3.

\section{Precision}

Repeatability was achieved by three replicate determinations of 0.5 , 1.5 and $3 \mu \mathrm{g} / \mathrm{spot}, 1,1.5,2 \mu \mathrm{g} / \mathrm{spot}$ and $1,2.5$ and $5 \mu \mathrm{g} / \mathrm{mL}$ for NP-TLC, RP-TLC and MLC methods, respectively on three successive times in the same day. Intermediate precision was performed as repeatability but on three successive days. Small values of \%error and \%RSD 
Citation: $\quad$ Rizk M, Taha EA, El-Alamin MMA, Sayed YM (2017) Stability-Indicating Chromatographic Methods for Determination of Agomelatine in

Page 5 of 9

revealed the precision of the proposed method. The results are illustrated in Table 4.

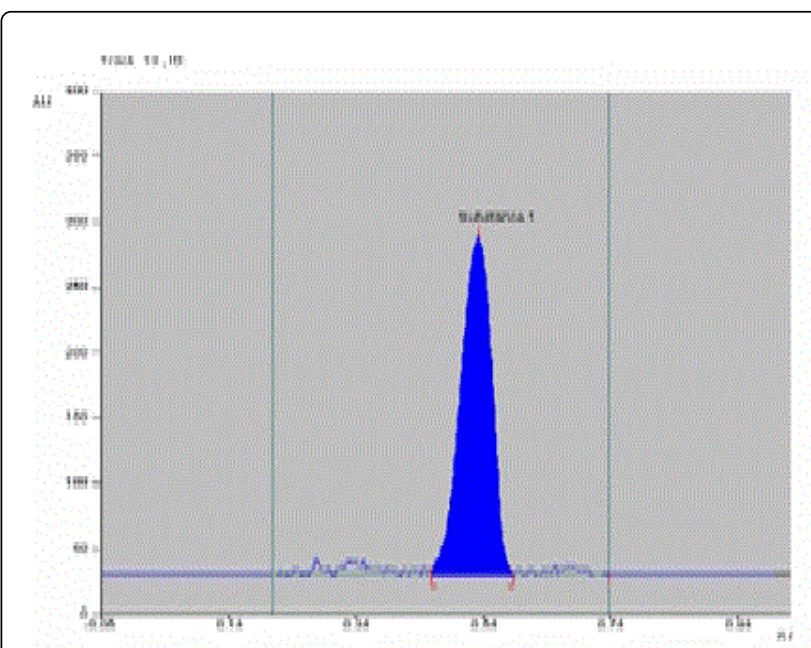

Figure 4: $2 \mathrm{D}$ chromatogram of $\mathrm{AGO}(\mathrm{Rf}=0.54 \pm 0.02)$ using $0.1 \%$ TEA: Acetonitril $(60: 40, \mathrm{v} / \mathrm{v}) \mathrm{PH}=2$ as mobile phase at $280 \mathrm{~nm}$ by RP-TLC method.

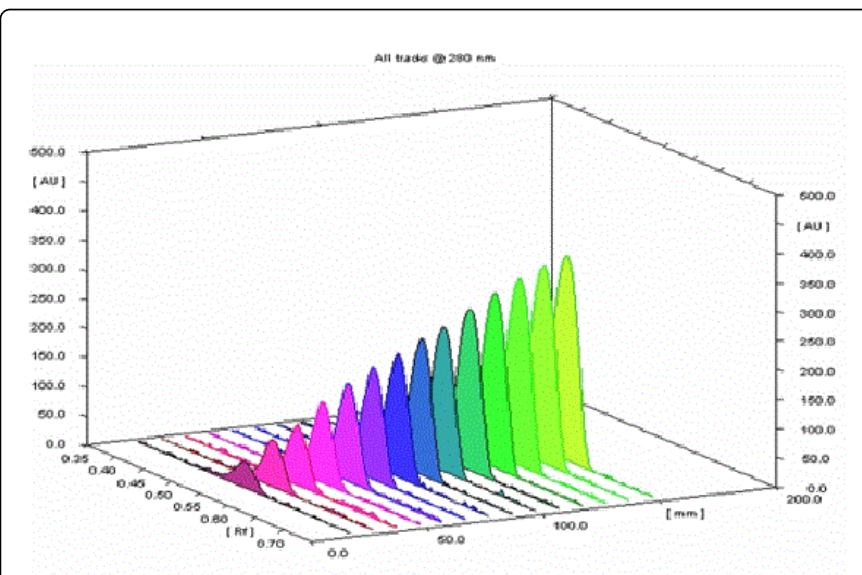

Figure 5: 3D chromatogram of calibration bands of AGO (0.3-4 $\mu \mathrm{g} /$ spot) at $280 \mathrm{~nm}$ by RP-TLC.

\section{Specificity}

The Specificity of the proposed NP-TLC, RP-TLC and MLC methods were established by their ability to determine AGO in commercial tablets without interference from common tablet additives. The common tablets additives did not show any interfering peaks at the retention times or RF values of the drug. The results are illustrated in Table 5. Forced degradation studies were also performed to assess the validity of the methods. The results obtained indicated that the three methods are specific and able to determine AGO in presence of its degradation products.

\section{Sample solution stability}

Evaluation of the stability of AGO solution was achieved by quantification of AGO on three successive days and comparison to freshly prepared solution. No significant changes were observed in standard solution response, proved that it was stable up to 3 days when kept stored in refrigerator.

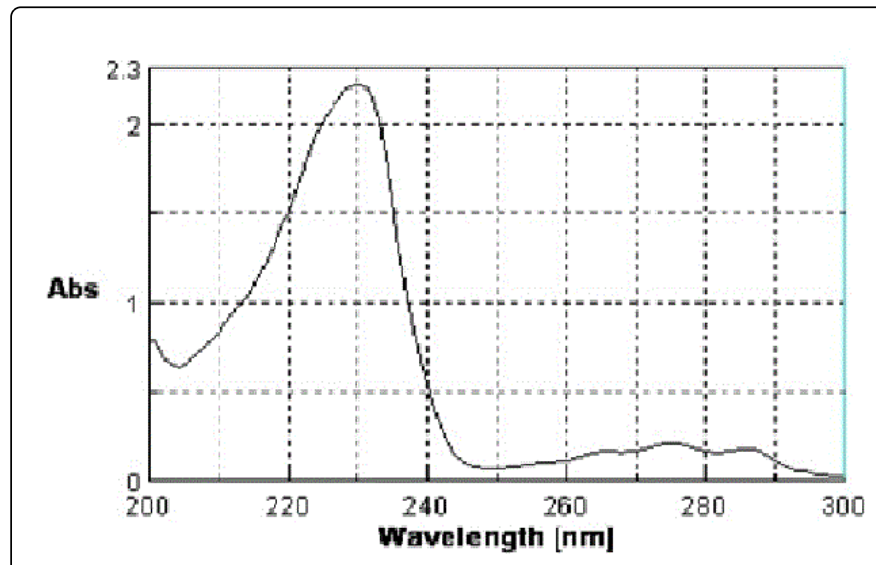

Figure 6: Absortion spectrum of AGO in $\mathrm{MeOH}$.

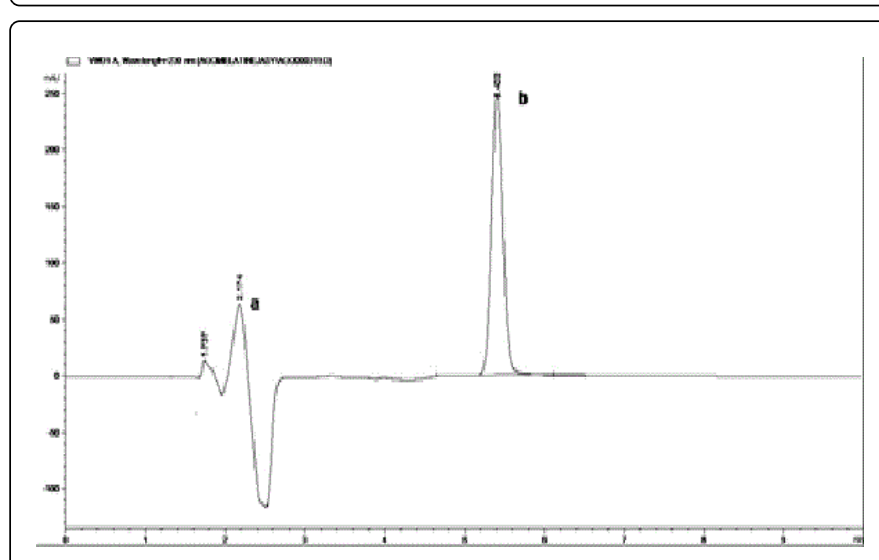

Figure 7: MLC Chromatogram of AGO under optimum chromatographic conditions using Apollo $\mathrm{C}_{18}$ column (a) solvent front peak (b) AGO peak $(5 \mu \mathrm{g} / \mathrm{mL})$.

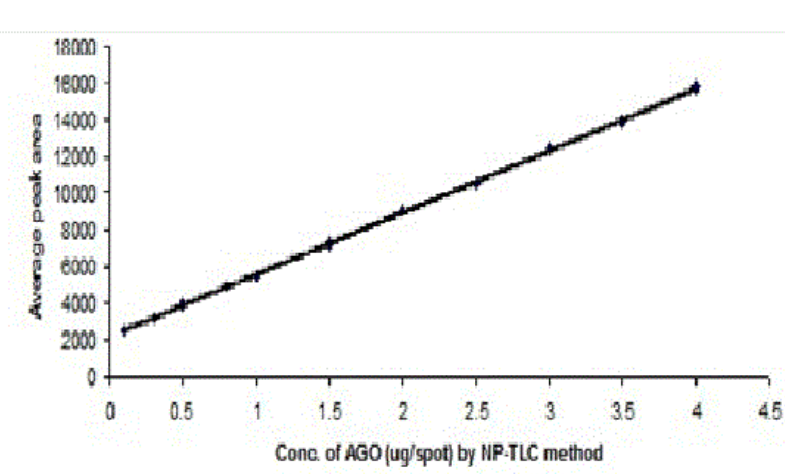

Figure 8: Calibration curve for NP-TLC method of AGO. 
Citation: $\quad$ Rizk M, Taha EA, El-Alamin MMA, Sayed YM (2017) Stability-Indicating Chromatographic Methods for Determination of Agomelatine in Drug Substance and Drug Product. Pharm Anal Acta 8: 531. doi:10.4172/2153-2435.1000531

Page 6 of 9

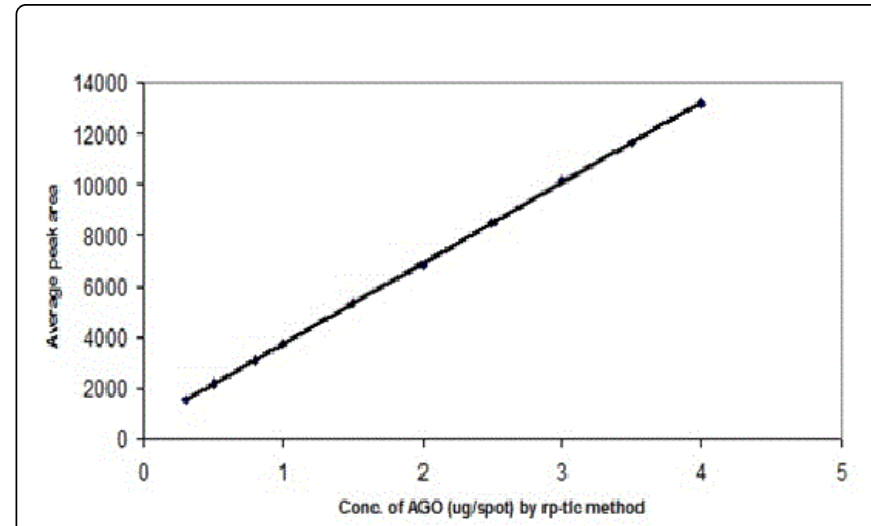

Figure 9: Calibration curve for RP-TLC method of AGO.

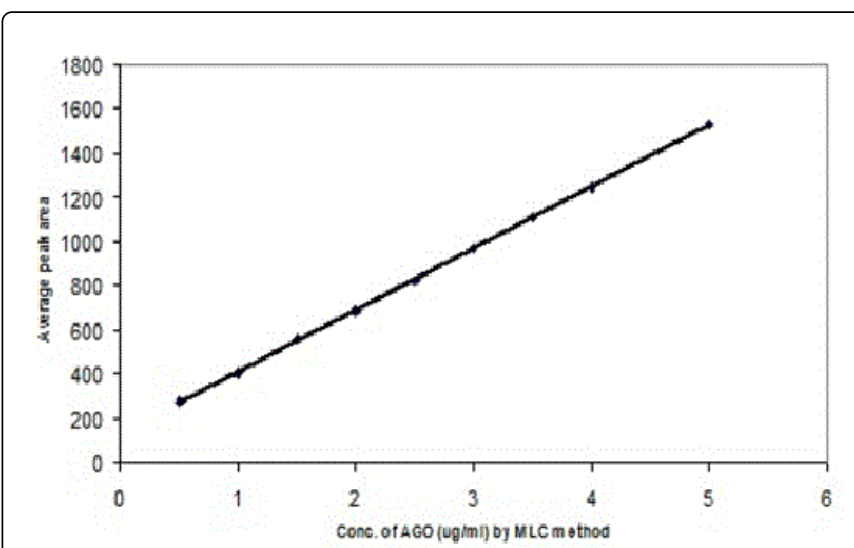

Figure 10: Calibration curve for MLC method of AGO.

\section{Robustness}

For NP-TLC method: Small changes in the mobile phase composition of ethyl acetate- methanol-ammonia (33\%) (8.4:1.2:0.4 $\mathrm{v} / \mathrm{v} / \mathrm{v})$ and $(8.6: 0.8: 0.6 \mathrm{v} / \mathrm{v} / \mathrm{v})$, saturation time $(10 \pm 1 \mathrm{~min}$.$) and$ different wavelengths $(229 \pm 1 \mathrm{~nm})$ were introduced, then examining their effects on the obtained results.
For RP-TLC method: Small changes in the mobile phase composition of $0.1 \%$ TEA: Acetonitril $(6.2: 3.8, \mathrm{v} / \mathrm{v})$ and $(5.8 .: 4.2, \mathrm{v} / \mathrm{v})$, saturation time $(15 \pm 1 \mathrm{~min}$.$) and different wavelengths (280 \pm 1 \mathrm{~nm})$ were studied showing no effects on the obtained results.

For MLC method: Small changes in concentration of butan-1-ol (15 $\pm 0.5 \%, \mathrm{v} / \mathrm{v})$, concentration of TEA $(0.2 \pm 0.05 \%)$, $\mathrm{PH}$ of the mobile phase $(3 \pm 0.1)$ and wavelength $(230 \pm 1 \mathrm{~nm})$ were studied. The efficiency of the separation of AGO was not affected indicating the robustness of the proposed MLC method.

Therefore, all methods are robust to the small changes in experimental conditions.

\section{Applications}

Application of the proposed TLC and MLC methods for the determination of AGO in tablet: The developed methods were applied successfully for the assay of AGO in commercial tablets. The results obtained were statistically compared with those of the reference HPLC method [17] using the t-test and F-test. The results showed that there were no significant differences between the developed and reference methods regarding accuracy and precision as illustrated in Table 5.

Application of standard addition technique for the determination of AGO in its tablet: Validity of the proposed methods was also assessed using the standard addition technique by adding known different amounts of bulk powder AGO to a known concentration of the tablets. The good recoveries assured the accuracy of the methods (Table 6).

\section{Results of Stress Testing Studies}

Stability testing of AGO was performed under various stress conditions according to ICH guidelines [16] in order to assure the selectivity and provide an indication of the stability-indicating properties of the three methods.

The studied compound is found to be highly labile to acidic and alkaline hydrolysis as illustrated in (Figures 11 and 12) respectively by MLC method and (Figures 13 and 14) respectively by RP-TLC method. Exposure of AGO tablets to oxidative degradation by $5 \% \mathrm{v} / \mathrm{v} \mathrm{H}_{2} \mathrm{O}_{2}$ was illustrated in Figure 15 by RP-TLC method. AGO did not exhibit any degradation peaks that could interfere with the proposed MLC and RP-TLC methods.

\begin{tabular}{|l|l|l|l|}
\hline Parameters & NP-TLC method & RP-TLC method & MLC method \\
\hline Linearity and range & $(0.1-4 \mu \mathrm{g} / \mathrm{spot})$ & $(0.3-4 \mu \mathrm{g} / \mathrm{spot})$ & $(0.5-5 \mu \mathrm{g} / \mathrm{mL})$ \\
\hline Slope & 3400.20 & 3163.79 & 277.58 \\
\hline Intercept & 2149.55 & 585.10 & 134.99 \\
\hline Correlation coefficient $\left(\mathrm{r}^{2}\right)$ & 0.9997 & 0.9998 & 0.9999 \\
\hline LOD & $0.009 \mu \mathrm{g} / \mathrm{spot}$ & $0.017 \mu \mathrm{g} / \mathrm{spot}$ & $0.119 \mu \mathrm{g} / \mathrm{mL}$ \\
\hline & $0.028 \mu \mathrm{g} / \mathrm{spot}$ & $0.051 \mu \mathrm{g} / \mathrm{spot}$ & $0.361 \mu \mathrm{gg} / \mathrm{mL}$ \\
\hline
\end{tabular}

Table 2: The regression data for the determination of AGO using three methods. 
Citation: $\quad$ Rizk M, Taha EA, El-Alamin MMA, Sayed YM (2017) Stability-Indicating Chromatographic Methods for Determination of Agomelatine in Drug Substance and Drug Product. Pharm Anal Acta 8: 531. doi:10.4172/2153-2435.1000531

Page 7 of 9

\begin{tabular}{|c|c|c|c|c|c|c|c|c|c|}
\hline \multicolumn{3}{|c|}{ For NP-TLC method } & \multicolumn{3}{|c|}{ For RP-TLC method } & \multicolumn{3}{|c|}{ For MLC method } & \multirow{2}{*}{$\begin{array}{l}\text { Reference } \\
\text { method }^{*}\end{array}$} \\
\hline $\begin{array}{l}\text { Conc. taken } \\
(\mu \mathrm{g} / \mathrm{mL})\end{array}$ & $\begin{array}{l}\text { Conc. found } \\
(\mu \mathrm{g} / \mathrm{mL})\end{array}$ & $\%$ Recovery & $\begin{array}{l}\text { Conc. taken } \\
\text { ( } \mu \mathrm{g} / \mathrm{spot} \text { ) }\end{array}$ & $\begin{array}{l}\text { Conc. found } \\
\text { ( } \mu \mathrm{g} / \mathrm{spot})\end{array}$ & $\%$ Recovery & $\begin{array}{l}\text { Conc. taken } \\
\text { ( } \mu \mathrm{g} / \mathrm{spot})\end{array}$ & $\begin{array}{l}\text { Conc. found } \\
\text { ( } \mu \mathrm{g} / \mathrm{spot})\end{array}$ & $\%$ Recovery & \\
\hline 0.5 & 0.502 & 100.47 & 1.0 & 1.000 & 100.03 & 0.5 & 0.508 & 101.60 & 100.23 \\
\hline 1 & 0.989 & 98.86 & 1.5 & 1.51 & 101.04 & 1.5 & 1.528 & 101.83 & 100.82 \\
\hline 2 & 2.026 & 101.31 & 2.0 & 1.965 & 98.26 & 2.5 & 2.486 & 99.43 & 101.80 \\
\hline 3 & 3.028 & 100.93 & 2.5 & 2.515 & 100.58 & 3.5 & 3.502 & 100.05 & 101.71 \\
\hline 4 & 4.015 & 100.36 & 3.0 & 3.028 & 100.93 & 5 & 5.015 & 100.30 & 101.15 \\
\hline Mean \pm RSD & \multicolumn{2}{|l|}{$100.39 \pm 0.930$} & \multicolumn{3}{|l|}{$100.17 \pm 1.135$} & \multicolumn{3}{|l|}{$100.64 \pm 1.027$} & $101.14 \pm 0.643$ \\
\hline t-test & \multicolumn{2}{|c|}{$0.1758(2.3060)^{\star *}$} & \multicolumn{3}{|l|}{0.1349} & \multicolumn{3}{|l|}{0.3972} & - \\
\hline F-test & \multicolumn{2}{|c|}{$2.0610(6.3882)^{\star \star}$} & \multicolumn{3}{|l|}{3.0573} & \multicolumn{3}{|l|}{2.5275} & - \\
\hline
\end{tabular}

Table 3: Accuracy of the proposed TLC and MLC methods for the determination of AGO. *Each result is the average of three separate determinations [17], ${ }^{* *}$ Values between parentheses are the tabulated $t$ and $F$ values at $n=5$ and $p=0.05$ [18].

\begin{tabular}{|l|l|l|l|}
\hline Parameters & $\begin{array}{l}\text { For NP-TLC } \\
\text { method }\end{array}$ & $\begin{array}{l}\text { For RP-TLC } \\
\text { method }\end{array}$ & For MLC method \\
\hline $\begin{array}{l}\text { Repeatability } \\
\% \text { Found } \pm \text { SD } \\
\% \text { RSD }\end{array}$ & $\begin{array}{l}100.70 \pm 1.321 \\
\text { \% Error }\end{array}$ & $\begin{array}{l}99.55 \pm 0.824 \\
0.827\end{array}$ & $\begin{array}{l}100.17 \pm 0.973 \\
0.972\end{array}$ \\
\hline $\begin{array}{l}\text { Intermediate } \\
\text { precision }\end{array}$ & $100.05 \pm 1.146$ & 0.276 & 0.324 \\
$\%$ Found \pm SD & 1.145 & 1.262 & $1.56 \pm 1.256$ \\
\% RSD & 0.382 & 0.419 & 1.131 \\
$\%$ Error & & & 0.377 \\
\hline
\end{tabular}

Table 4: Precision data of the proposed TLC and MLC methods for the determination of AGO.

\begin{tabular}{|l|l|l|l|l|}
\hline Parameters & $\begin{array}{l}\text { For NP-TLC } \\
\text { method }\end{array}$ & $\begin{array}{l}\text { For RP-TLC } \\
\text { method }\end{array}$ & $\begin{array}{l}\text { For MLC } \\
\text { method }\end{array}$ & $\begin{array}{l}\text { Reference } \\
\text { method** }^{* *}\end{array}$ \\
\hline Mean\% \pm SD & $\begin{array}{l}101.53 \\
1.299\end{array}$ & $101.34 \pm 0.970$ & $99.97 \pm 1.173$ & $\begin{array}{l}100.94 \\
1.031\end{array}$ \\
\hline $\mathrm{N}$ & 5 & 5 & 5 & 5 \\
\hline Variance & 1.688 & 0.941 & 1.672 & 1.063 \\
\hline t-test & $\begin{array}{l}0.4466 \\
(2.3060)^{*}\end{array}$ & 0.5459 & 0.6106 & - \\
\hline F-test & $\begin{array}{l}1.5882 \\
(6.3882)^{*}\end{array}$ & 1.1296 & 1.5730 & - \\
\hline
\end{tabular}

Table 5: Application of the proposed TLC and MLC methods for the determination of AGO in tablets. ${ }^{*}$ Values between parentheses are the tabulated $\mathrm{t}$ and $\mathrm{F}$ values at $\mathrm{p}=0.05[18] ;{ }^{* *}$ Reference method is the company method [17].

\begin{tabular}{|c|c|c|c|c|c|c|c|c|}
\hline \multicolumn{3}{|c|}{ For NP-TLC method } & \multicolumn{3}{|c|}{ For RP-TLC method } & \multicolumn{3}{|l|}{ For MLC method } \\
\hline $\begin{array}{l}\text { Claimed } \\
\text { amount taken } \\
\text { ( } \mu \mathrm{g} / \mathrm{spot})\end{array}$ & $\begin{array}{l}\text { pure added } \\
\text { ( } \mu \mathrm{g} / \mathrm{spot})\end{array}$ & $\%$ Recovery & $\begin{array}{l}\text { Claimed } \\
\text { amount taken } \\
\text { ( } \mathrm{gg} / \mathrm{spot})\end{array}$ & $\begin{array}{l}\text { pure added } \\
\text { ( } \mathrm{gg} / \mathrm{spot})\end{array}$ & $\%$ Recovery & $\begin{array}{l}\text { Claimed } \\
\text { amount taken } \\
(\mu \mathrm{g} / \mathrm{mL})\end{array}$ & $\begin{array}{l}\text { pure added } \\
(\mu \mathrm{g} / \mathrm{mL})\end{array}$ & $\%$ Recovery \\
\hline \multirow[t]{3}{*}{0.5} & 0.5 & 98.09 & \multirow[t]{3}{*}{1} & 0.5 & 99.94 & \multirow[t]{3}{*}{1} & 0.5 & 100.63 \\
\hline & 1 & 98.01 & & 1 & 100.93 & & 1 & 100.10 \\
\hline & 1.5 & 99.10 & & 2 & 100.00 & & 2 & 98.81 \\
\hline Mean \pm SD & \multicolumn{2}{|l|}{$98.40 \pm 0.604$} & \multicolumn{3}{|l|}{$100.29 \pm 0.555$} & \multicolumn{3}{|l|}{$99.85 \pm 0.939$} \\
\hline
\end{tabular}

Table 6: Application of standard addition technique for the determination of AGO in its drug product by the proposed TLC and MLC methods. 
Citation: $\quad$ Rizk M, Taha EA, El-Alamin MMA, Sayed YM (2017) Stability-Indicating Chromatographic Methods for Determination of Agomelatine in

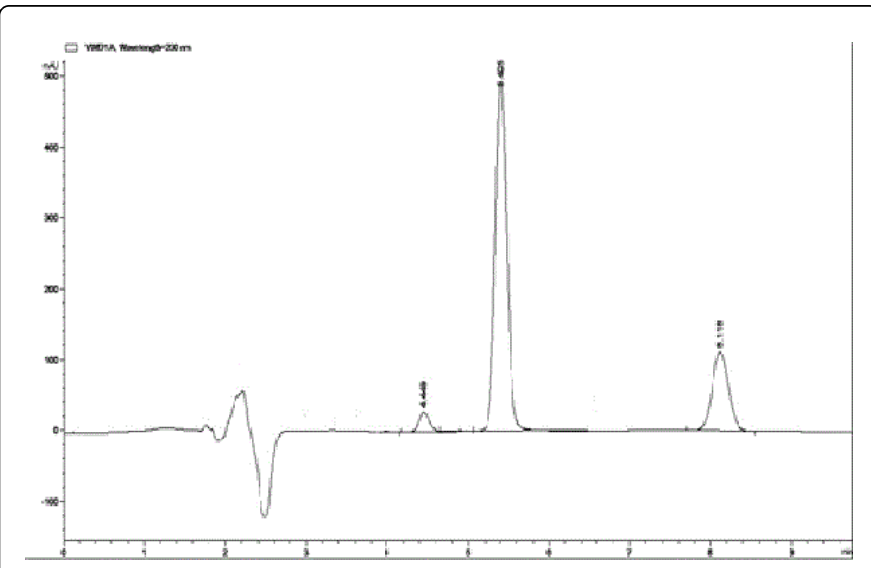

Figure 11: Acid forced degradation chromatogram of AGO by MLC method.

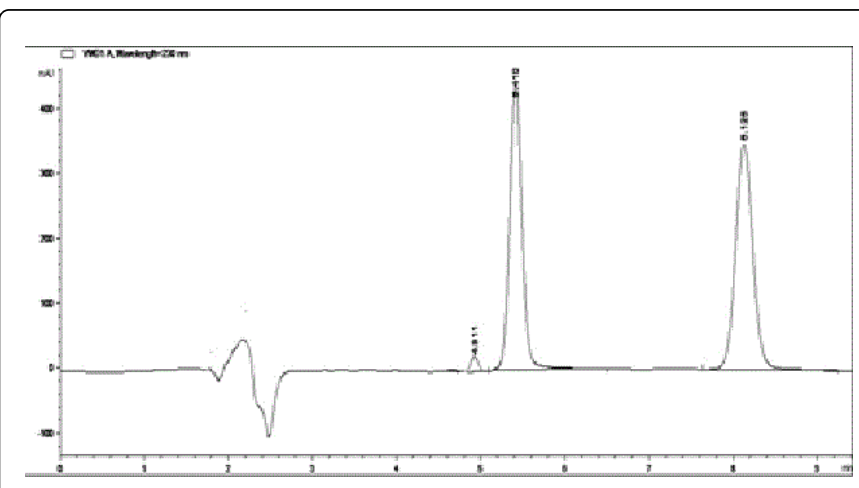

Figure 12: Alkali forced degradation chromatogram of AGO by MLC method.

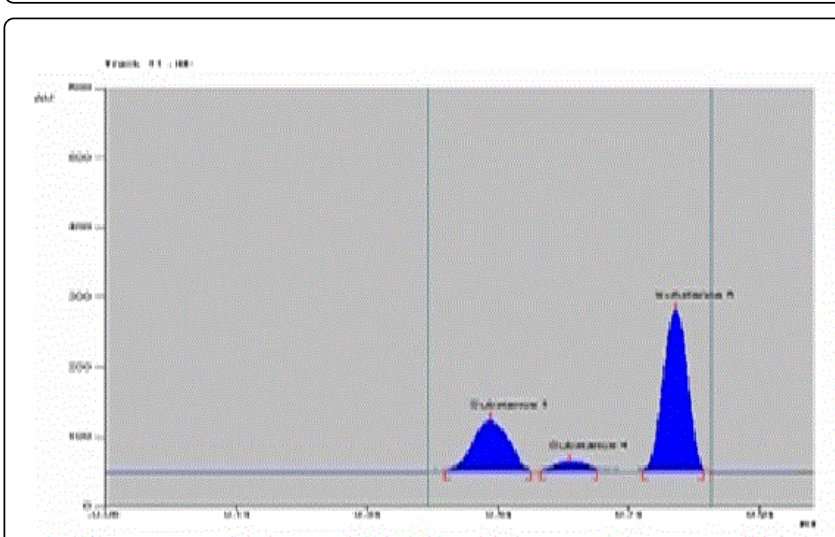

Figure 13: Acid forced degradation chromatogram of AGO by RPTLC method.

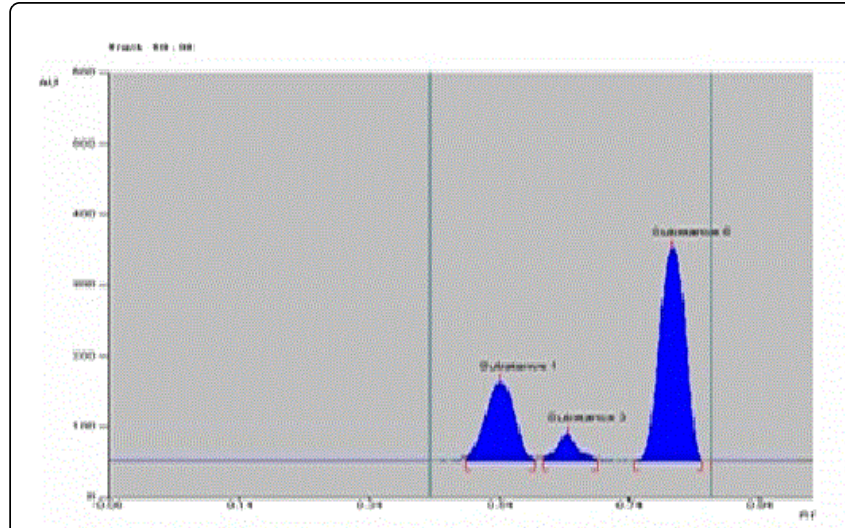

Figure 14: Alkali forced degradation chromatogram of AGO by RPTLC method.

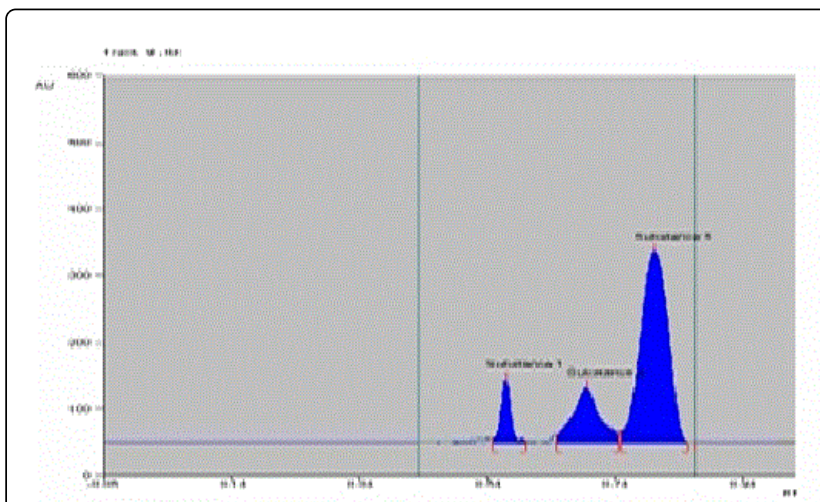

Figure 15: Oxidative forced degradation chromatogram of AGO by RP-TLC method.

\section{Conclusion}

The proposed MLC, NP-TLC and RP-TLC methods represent accurate and sensitive stabilityindicating assay for identification and quantification of AGO in bulk and pharmaceutical dosage form. All validation parameters were found to be highly satisfactory. Hence, the method was successfully validated in accordance with ICH guidelines. It can be conveniently used for routine QC analysis and stability studies of AGO without any interference from excipients and degradation products.

\section{Acknowledgment}

The authors are thankful to Raw Material Lab. Staff in National Organization for Drug Control and Research (NODCAR) for providing analytical facilities.

\section{References}

1. Cardinali DP, Vidal MF, Vigo DE (2012) Agomelatine: It's Role in the Management of Major Depressive Disorder. Clinical Medicine Insights: Psychiatry 4: 1-23.

2. (2006) The Merck Index (14th edn.). Merck and Co., INC., Rahway, USA. 
Citation: Rizk M, Taha EA, El-Alamin MMA, Sayed YM (2017) Stability-Indicating Chromatographic Methods for Determination of Agomelatine in Drug Substance and Drug Product. Pharm Anal Acta 8: 531. doi:10.4172/2153-2435.1000531

Page 9 of 9

3. Rao PV, Prabhakar T, Naveen CR, Ramakrishna S, Trinath G (2010) Clinical and pharmacological review on novel melatonergic antidepressant:Agomelatine. J Pharm Bio Chem Sci 1: 446-450.

4. Saracino MA, Mercolini L, Carbini G, Volterra V, Quarta AL, et al. (2014) Multi-matrix assay of the first melatonergic antidepressant agomelatine by combined liquid chromatography-fluorimetric detection and microextraction by packed sorbent. J Pharm Biomed Anal 95: 61-67.

5. El-Shaheny RN (2014) Evaluation of agomelatine stability under different stress conditions using an HPLC method with fluorescence detection application to the analysis of tablets and human plasma. J Bio Chem Lumin 29: 920-928.

6. Meghana M, Thota S, Venisetty RK (2014) Development and validation of stability indicating RP-HPLC method for the estimation of agomelatine in API. J Pharm Bio Chem Sci 5: 621-628.

7. Rashed NS, Fouad MM, Attia AK, Wasfy RA (2014) Validated stability indicating high performance liquid chromatography and spectroscopic methods for determination of agomelatine. World J Pharm Sci 3: 113-124.

8. Liu YX, Chen L, Ji YB (2013) Quantification and structural elucidation of potential impurities in agomelatine active pharmaceutical ingredient. J Pharm Biomed Anal 81: 193-201.

9. Patil SR, Nerurkar KK, Kalamkar AM, Pukale V, Mangaonkar KV, et al. (2012) Validated LC-MS/MS method for quantification of agomelatine in human plasma and its application in a pharmacokinetic study. J Mass Spectromet 47: 23-28.
10. Ogawa T, Iwai M, Hattori H, Zaitsu K, Kumazawa T, et al. (2014) Highthroughput analysis of ramelteon, agomelatine, and melatonin in human plasma by ultra-performance liquid chromatography-tandem mass spectrometry. Forensic Toxicol 32: 126-131.

11. Lipka E, Landagaray E, Ettaoussi M, Yous S, Vaccher C (2014) Enhanced detection for determination of enantiomeric purity of novel agomelatine analogs by EKC using single and dual cyclodextrin systems. Electrophoresis 35: 1-8.

12. Joshi HS, Rupareliya RH (2013) Stability-indicating HPTLC method for quantitative estimation of agomelatine in bulk and pharmaceutical dosage form. World J Pharm Sci 2: 5591-5601.

13. Shas DA, Nakrani RS, Baldania SL, Chhalotiya UK, Bahatt KK (2012) Development and Validation of HPTLC Method for the Estimation of Desvenlafaxine in Tablet Formulation. J Planar Chromatogra 25: 174-177.

14. Armstrong D, Henry S (1980) J Liq Chromatogr R T 3: 657-662.

15. http://www.sciencedirect.com/science/article/pii/002196739400451X

16. http://www.bioforum.org.il/Uploads/Editor/karen/q2_r1_step4.pdf

17. HPLC method adopted by Servier Egypt Industries Limited, Giza, ARE.

18. Miller JC, Miller JN (2005) Statistics and Chemometrics for Analytical Chemistry (5th edn.). Pearson Education Limited: Harlow, England, pp: 39-73. 